\title{
Geology as Theater: The Earth on Show: Fossils and the Poetics of Popular Science, 1802-1856, by Ralph O'Connor
}

\author{
Chicago: University of Chicago Press, 2007. Pp. xiii + 541. H/b \$45.00.
}

\section{Steven Newton}

Published online: 23 April 2010

(C) Springer Science+Business Media, LLC 2010

Keywords History of geology · Popularization of science . Paleontology · Dinosaurs · Charles Lyell .

Principles of Geology · Gideon Mantell

How should scientists present their findings to the public? How does popularization of science affect interpretations in fledging disciplines, such as geology in the first half of the nineteenth century? How did the British public react to popular paleontology in the early Victorian era? Such questions are the focus of Ralph O'Connor's book The Earth on Show.

O'Connor does an admirable job of bringing the reader into the pre-Darwinian nineteenth century, and giving insight into the mindset of a public curious about the new, terrifying "monsters" being unearthed by geologists. O'Connor's observations on the popularization of science also have relevance to the problems facing scientists today in presenting meaningful scientific information to a public conditioned for flashy presentations and short attention spans.

Beginning with a discussion of the first full reconstruction of mammoth skeletons in 1802, O'Connor shows how scientists of that age were, in large part, showmen who blended science with spectacle, and who garnered public interest with dramatic - and at times, scientifically problematic - displays of their discoveries.

Noting that "[p]opular science in the early-Victorian period was not a coherent or stable entity, but a battlefield

\section{S. Newton $(\triangle)$}

National Center for Science Education,

420 40th Street, Suite 2,

Oakland, CA 94609, USA

e-mail: newton@ncse.com or marketplace" (p. 213), O’Connor argues that geology succeeded, in large part, "by presenting its objects as historical antiquities, romantically evocative of bygone eras" (p. 61). This view of geology was simultaneously "comfortingly traditional and attractively novel" (p. 72) to audiences.

Early geology unleashed "a procession of bizarre extinct reptiles lurch[ing] into the limelight" (p. 159) and into the pubic imagination. Although modern audiences take the existence of fantastic creatures for granted, in the first half of the nineteenth century such creatures were striking and unusual:

For many people today ... watching a television programme about dinosaurs is not a particularly challenging experience. These ancient monsters, half fact, half fiction, are a familiar part of our world-view ... We therefore need to make a monumental effort of imagination when trying to think ourselves into the position of the uninitiated general reader in, say, the mid-1830s. (p. 200)

One technique in early geological presentations was to use "word-painting techniques" (p. 187), which often involved "quotations from modern poetry at climactic moments" (p. 197). The point of such flowering verse was to transport the reader's mind beyond dry descriptive text. The rhetoric of such early geologists attempted to turn science into "a form of time travel" (p. 154). Geology allowed readers to "travel into alien landscapes" (p. 320) populated with strange beasts so large and bizarre as to appear mythological.

Indeed, one way early geologists presented dinosaurs was to explicitly link them to dragons. Illustrations depicting Iguanodon portrayed it "as a dragon, complete with pointy tail, enhanc[ing] the scene's fantastic nature" 
(p. 97). Such reconstructions were not, of course, based upon any fossil evidence, but were a fanciful interpretation meant to achieve a specific purpose.

O'Connor asks, "Why were these ancient creatures demonized? ... Why monsters rather than simply 'extinct animals'?" (p. 422). One answer is simply that this was a more dramatic way to present fossils, and therefore more likely to attract a paying audience. But O'Connor also sees overly dramatic phrases used to describe fossils coming not only from attempts to popularize geology, but even from the language within the scientific community itself. In a later example from 1905, O'Connor notes that Tyrannosaurus rex became not just a large fossil, but the King of the Tyrant Lizards. This, O'Connor argues, "maintained the old view of the antediluvian world as ruled by gigantic tyrants" (p. 423).

Did this tendency to overdramatize lead to misinterpretation of the fossils? O'Connor argues that monstrosity was a central issue in the struggle between accurate reconstructions, and representations that would capture the public's imagination. Once a monstrous image for a particular fossil gained a foothold in the public imagination, it tended to enjoy longevity:

The pterodactyl's image, to take one example, was more or less fixed in the 1830 s by Buckland's Miltonic description... In this form it passed on into twentieth century prose romances as an emblem of atavism, appearing as 'the devil of our childhood in person' in the London of Conan Doyle's Lost World (1912) and transformed into the Witch-King's hellish steed in J.R.R. Tolkien's Lord of the Rings (1953-55). (p. 422)

Just as fossils were interpreted in the early nineteenth century as something other than extinct animals, earthquakes and volcanoes - which today we consider normal geologic processes-were portrayed as apocalyptic, worldending events that had not only geologic but also political significance:

Apocalyptic spectacle in the late eighteenth and early nineteenth centuries was informed by a marked shift in how the past was viewed. Convulsive demographic and socio-economic change, and the rapid transformation of the British landscape, sharpened the sense of the past as another country ... violent physical causes like earthquakes and floods had gained new associations, and painting of (super) natural disasters routinely invited political interpretation. (p. 301)

The politics of scientific spectacle were conditioned, however, by the high costs of this new science. Simply put, most geology in the early nineteenth century was far beyond the economic reach of the public.
In one of the strongest sections of O'Connor's book, he investigates how much it would have cost to view the new, exciting fossils being displayed in the early nineteenth century. Entry into Gideon Mantell's famous museum, for example, cost a shilling, which amounted to half a day's wages for average British tradesmen. The costs of joining the Bristol Institute, a center of vertebrate paleontology, ran an entire year's salary for an average laborer, with the annual renewal costing an entire month's wages. Clearly, viewing fossil exhibits through such venues was limited to a narrow portion of the public.

Many collections and museums were open only by invitation. Institutions such as the British Association for the Advancement of Science offered lectures - but only to invited guests. The British Museum refused entry on the basis of the quality of would-be visitors' clothing and hygiene. The audience addressed by early geologist popularizers, then, was a specific economic and social range. While today we might think of popular science appealing to the broadest audience, the early history of geology is better characterized by exclusion.

To typical British wage-earners during the first half of the nineteenth century, such exclusions were not necessarily looked upon as a great loss. As O'Connor notes,

Workers in the nineteenth century were not easily persuaded that they needed [these] kinds of polite science ... A knowledge of earth history was of limited practical use to most of them, and not many were convinced that it could be a worthwhile form of entertainment. (p. 224)

The popularization of science was no better when it came to books. Charles Lyell produced two editions of his seminal Principles of Geology, but the less expensive version would still have cost a day's wages for the average worker. Even consumers of relatively inexpensive books such as The Little Geologist "would not necessarily be thrilled to see more than half the day's earnings spent on a little pink book about stones" (p. 220). Another barrier to popularization of geology through books was the fact that "over 30 percent of the British population were illiterate, and a further 30 to 50 percent were semi-literate" (p. 224).

Literate or not, most people at this time were quite aware of biblical accounts of creation and presumed that science would confirm, rather than conflict with, scriptural accounts of the earth's past. As O'Connor writes, "The fossil record, or 'Great Book of Dead Times' emerges as, in effect, a newly discovered book of the Bible in stone" (p. 231).

However, the science of geology, from Hutton onwards, showed a distinctly old earth. When geologists such as Charles Lyell wrote about this fact for a general audience, they were confronted with a stark choice: 
The Bible's authority over earth history remained largely unchallenged, at least in public, and was reinforced by literalist writers on geology. Lyell saw no way out for his science other than to combat these writers head-on by demolishing the assumptions on which their approach rested, and denying all links between scripture and geological reasoning. (p. 165)

Geology in the early nineteenth century emerged, then, in conflict with literalist religious interpretations of earth's history:

Lyell wanted to dislodge the Bible's imaginative hold over a large segment of the British public, to show that geology offered grander (and hence, in this age, truer) views of the Creator's work. This ambitious project would be fully realized in his Principles of Geology (1830-3). (p. 167)

At the same time, Lyell sought to frame geology not as a radical, atheistic endeavor, but as a more accurate, and more entertaining, vision of the past. The first edition of Principles was expensive, and hence targeted as an audience what Lyell considered his most important demographic:

[T]he expensive first edition of the Principles targeted the conservative leisured classes: Lyell sought to reassure them that geology presented no threat to Christianity and offered no support for atheistic radicalism. But he also believed that correct natural knowledge should be "diffused" to the "vulgar" by an enlightened clerisy of gentlemen. (p. 184)

This "top-down" approach to science reflected Lyell's position on how science ought to be presented to the pubic. The hierarchy of social classes in Victorian Britain was to be preserved, even in how one transmitted scientific ideas:

Lyell had a strongly hierarchical vision of what "popularization" should involve... to present science as a body of authoritative, predigested information, communicated via extracts from the leading scientific periodicals, rather than as an ongoing conversation between its readers. (p. 185)

These social distinctions were even reflected in how the science was disseminated among the leisured classes. The divide between scientists and non-scientists was marked and clear. Scientists such as Lyell spread knowledge; his moneyed audience passively listened:

This perception of a clear gradient of knowledge between expert and public was integral to the new concept of popular science as 'rational amusement' provided from on high, delivered from the knowledgeable expert to his ignorant audience. (p. 198)

In this context geology became "the most popular science among the chattering classes," (p. 195), even as the larger public was aware only indirectly of the startling new findings being unearthed and dramatically presented in the early nineteenth century.

In conclusion, O'Connor's The Earth on Show presents a wide-ranging view of how geology, in its earliest days, appealed through drama and spectacle to an exclusive portion of the public. O'Connor writes:

The poetics of geology had been under construction for some time, and the same old techniques were still used: comparisons with romance, descriptions of huge monsters, folklore allusions, devotional rhapsodies, poetry quotations, vivid restorations of the past. (p. 196)

These presentations affected the scientific interpretations of fossils, turning dinosaurs into ferocious dragons and similarly populating the distant past with mythological creatures, all for the entertainment of the leisured classes. This presence of this spectacle in geology's past allows an interesting perspective into contemporary multimedia fossil expositions, such as Ida and Ardi, which were announced to the public with great fanfare. The spectacle-fueled exaggerations of the past can serve as a warning about how in the future to present scientific discoveries to the public. 